\title{
PROGRADAÇÃO DELTAICA E ALTERAÇÕES NA LINHA DE COSTA LAGUNAR NO PARQUE ESTADUAL DO CAMAQUÃ, RS
}

\author{
Ândrea Lenise de Oliveira Lopes ${ }^{(a)}$, Adriano Luís Heck Simon ${ }^{(\mathrm{b})}$ \\ (a) Programa de Pós-graduação em Geografia, Universidade Federal de Pelotas, lopes.andrea.geo@ gmail.com \\ (b) Departamento de Geografia e Programa de Pós-graduação em Geografia, Universidade Federal de Pelotas, \\ adriano.simon@ufpel.edu.br
}

\section{Eixo: DINÂMICA E GESTÃO DE ZONAS COSTEIRAS}

\begin{abstract}
Resumo
O trabalho foi desenvolvido com o objetivo de identificar e analisar a progradação deltaica e as alterações da linha de costa lagunar do Parque Estadual do Camaquã (RS) no período entre 1964 e 2012. Foram realizados dois mapeamentos da frente deltaica e da linha de costa lagunar por meio da interpretação de fotografias aéreas e imagens do satélite RapidEye. Três áreas principais de alteração foram identificadas: (1) na localidade do Pontal do Quilombo, com retração da linha de costa lagunar; (2) no Pontal do Vitoriano, onde ocorreu a expansão da linha de costa, e (3) na frente deltaica, onde ocorreu a progradação da área de sedimentação, desencadeando a formação de ilhas fluviais, barras de desembocaduras e a expansão da linha de costa. Conclui-se que a compreensão da dinâmica deltaica e da linha de costa é importante para a construção do zoneamento e do Plano de Manejo do Parque Estadual do Camaquã (RS).
\end{abstract}

Palavras chave: ambientes deltaicos; unidade de conservação da natureza; dinâmica flúvio-lacustre.

\section{Introdução}

O Parque Estadual do Camaquã (PEC) é uma unidade de conservação integral, localizado no litoral lagunar do estado do Rio Grande do Sul. O parque foi criado em 12 de março de 1975 por meio do Decreto Estadual 23.798, tendo como objetivo a proteção das matas e banhados da Pacheca ( $6^{\circ}$ distrito do município de Camaquã - RS) e do delta intra-lagunar do rio Camaquã. Contudo, apesar de existir há mais de 40 anos, até o momento esta unidade não conta com Plano de Manejo ou regularização fundiária.

No estado do Rio Grande do Sul, apenas 2,3\% das áreas costeiras estão protegidas sob a forma de unidades de conservação (FONSECA et al. 1999). Além disso, no estado se encontra a maior parte das unidades de conservação fantasmas, ou seja, que só existem em documentos oficiais, porém nunca foram implementadas efetivamente (HANSEN, 2007).

Em conformidade com Nicolodi (2002), das cerca de 4.500 áreas protegidas no mundo, apenas 850 incluem ambientes marinhos e costeiros, fato este que contrasta com a importância destes ambientes para a humanidade. 
O Parque Estadual do Camaquã (RS) apresenta biodiversidade típica dos Domínios fito-fisionômicos Pampa e Mata Atlântica sustentando diversas espécies nativas que se encontram ameaçadas de extinção principalmente pelas atividades antropogênicas, como o desmatamento e as queimadas. Além disso, o parque apresenta também uma geodiversidade peculiar rica em paleoformas e formas de origem flúviolacustre, com destaque para o delta intra-lagunar do rio Camaquã, de grande representatividade ambiental.

Deltas são acumulações costeiras, subaéreas e subaquosas localizadas na desembocadura de um rio ao encontrar um corpo receptor que pode ser um lago, laguna ou mar. Têm sua morfogênese e morfodinâmica atreladas aos processos de alteração do nível médio relativo do mar durante o Quaternário, ao uso da terra e a ação das ondas e marés da bacia receptora (SUGUIO, 2003; ROSSETTI, 2008; DOMINGUEZ, 1990; GUERRA \& GUERRA, 2008).

Ambientes deltaicos são dinâmicos, instáveis e frágeis, portanto exigem um monitoramento, pois sua dinâmica está condicionada aos eventos que podem ocorrer tanto à montante quanto a jusante do delta $\mathrm{e}$ que irão interferir em sua morfodinâmica e configuração espacial. Sistemas deltaicos inseridos no contexto de uma unidade de conservação integral possuem ainda maior importância, pois evidenciam espaços de ampliação da unidade de conservação e precisam ter sua evolução espaço-temporal compreendida a fim de ser constantemente revista pelos zoneamentos ambientais e pelo Plano de Manejo.

A progradação é um fenômeno comum em ambientes deltaicos, em especial deltas lacustres, pois nesses ambientes a força das ondas e das marés não se faz de forma tão agressiva como em deltas marítimos facilitando assim o acúmulo de sedimentos trazidos pelos canais fluviais e a consequente formação de ilhas arenosas (SUGUIO, 2003).

As linhas de costa são consideradas a interface do continente com as áreas costeiras, portanto sofrem influência de ambos os sistemas, além de serem condicionadas por eventos de ordem natural e antropogênica, o que reforça a importancia do monitoramento desses ambientes, afinal é nesse local que a interação dos procesos costeiros como a erosão praial e os processos construcionais se fazem de forma mais incisiva alterando sensilvelmente a configuração espacial da linha de costa (MUEHE, 2001).

O acompanhamento do comportamento migratório da linha de costa é um importante elemento para o planejamento costeiro e a gestão de territórios, como as unidades de conservação. No caso do Parque Estadual do Camaquã o conhecimento do comportamento da linha de costa auxiliará no zoneamento da unidade e consequentemente no Plano de Manejo.

De acordo com Muehe (2001), a modificação espaço-temporal da linha de costa se dá basicamente por pelo menos 4 fatores principais: (1) alterações do nível do mar; (2) modificações verticais do nível dos 


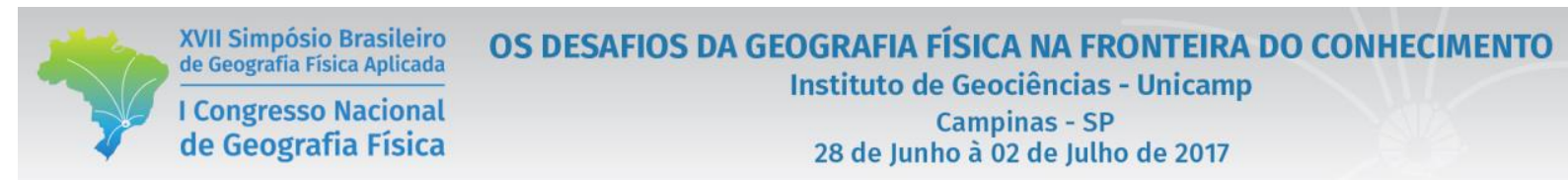

continentes (tectonismo); (3) reformatação da morfologia costeira por processos erosivos e deposicionais; e (4) alterações nos processos de interação terra-mar, como a amplitude das marés, a velocidade e direção dos ventos e energia de ondas. Cabe acrescentar ainda as características de ocupação das áreas costeiras, afinal entende-se que as atividades antropogênicas (turismo, especulação imobiliária, interceptação do aporte de água e sedimentos) sem o devido planejamento geram impactos na morfodinâmica costeira e na linha de costa (MARTINS, 2004).

Segundo Nicolodi (2002), estudos que visam o levantamento das alterações espaciais de linha de costa têm sido amplamente realizados por pesquisadores de zonas costeiras, porém estas pesquisas concentramse em ambientes marítimos, sendo escassos os estudos de alteração na faixa de praia em ambientes lagunares, sobretudo associados à sistemas deltaicos. No que se refere à progradação deltaica, Suguio (2003) salienta que este é um fenômeno comum em deltas intra-lagunares, pois nestes ambientes a energia das ondas é baixa, assim como a influência das marés, o que facilita a deposição de sedimentos na costa lagunar e dificulta seu retrabalhamento pelos processos costeiros.

A partir destas considerações iniciais, este trabalho foi desenvolvido com o objetivo de analisar a progradação deltaica e as alterações na linha de costa lagunar em área de abrangência do Parque Estadual do Camaquã/RS, em um período de 48 anos (1964 - 2012). O Parque Estadual do Camaquã se localiza na divisa dos municípios de Camaquã e São Lourenço do Sul, no Estado do Rio Grande do Sul (Figura 01).

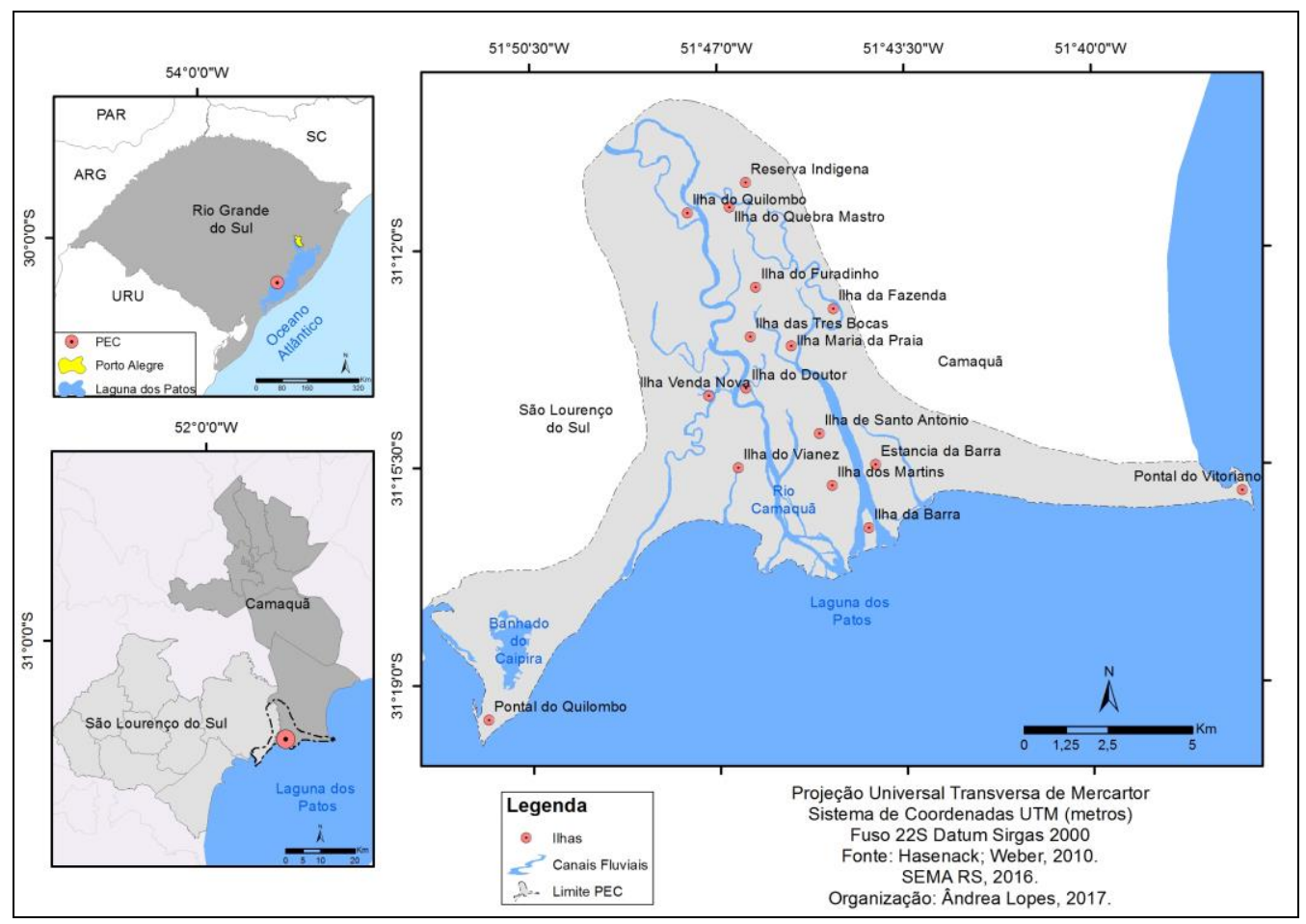

Figura 1 - Mapa de localização do Parque Estadual do Camaquã/RS 
Insere-se na Unidade Geomorfológica Planície Lagunar, abrangida pela Região Geomorfológica Planície Costeira Interna (RADAMBRASIL, 1986). Assenta-se sobre três unidades geológicas: Depósitos de Planície Lagunar composta por areia síltico-argilosa, Depósitos Deltáicos compostos por areia sílticoargilosa, silte e argila com restos orgânicos e Depósitos de Praias e cristas lagunares compostos por areias quartzosas finas a muito finas e bem selecionadas (CPRM, 2008).

Os depósitos de Planície Deltaica são extremamente sensíveis ao tipo de clima dominante. Em áreas de clima úmido e quente costumam exibir vegetação luxuriante (SUGUIO, 2003). O clima local apresenta precipitações com média anual de $1.213 \mathrm{~mm}$ e média mensal de 101,08mm. De acordo com a classificação de Köppen, (1900) o clima regional se enquadra como Temperado Úmido (Cfa).

A bacia receptora exerce importante influência na configuração espacial dos deltas (ROSSETI, 2008; SUGUIO, 2003). Fatores como altura das ondas (que controlam os processos erosivos na planície interdistributária e na dispersão da carga sedimentar trazida pelo rio), presença e altura das marés (que interferem nas cheias da planície distributária e retrabalham os sedimentos deltaicos selecionando-os) e profundidade do corpo receptor (que atua na configuração espacial das partes subaéreas e subaquosas) são fundamentais na configuração espacial e comportamento dos deltas.

A Laguna dos Patos, corpo receptor do delta intra-lagunar do rio Camaquã, possui uma extensão de $9.800 \mathrm{~km}^{2}$, com uma profundidade inferior à $-6 \mathrm{~m}$ (considerada como rasa, de acordo com Toldo Jr., 1994) sendo pouco influenciada pela maré astronômica. Esse sistema lagunar se desenvolve paralelo à linha de costa do litoral do Rio Grande do Sul, onde encontra-se abrigada dos sistemas costeiros por meio de um sistema de barreiras arenosas. Porém é influenciada pelas águas oceânicas através do canal de Rio Grande onde a vazão média é de $4.800 \mathrm{~m}^{3} / \mathrm{s}$ (NICOLODI, 2002), atuando como uma extensa bacia de drenagem, com cerca de $201.626 \mathrm{~km}^{2}$, dividindo-se em dois grandes complexos hidrográficos: Patos e Mirim (MARQUES, 2005).

\section{Metodologia}

A fundamentação teórico-metodológica apresentada neste estudo propõe a combinação da análise de fotografias aéreas e imagens de satélite dos anos de 1964 e 2012, respectivamente, para a caracterização do comportamento migratório da linha de costa lagunar e da progradação deltaica no Parque Estadual do Camaquã.

Para a vetorização da linha de costa e do delta do Camaquã no cenário de 1964 foram utilizadas oito fotografias aéreas pancromáticas na escala aproximada de 1:40.000, datadas de dezembro de 1964 e disponibilizadas pela Secretaria de Planejamento do Rio Grande do Sul (SEPLAN-RS). As fotografias 
aéreas foram digitalizadas e exportadas para o software StereoPhotoMaker para a geração de anaglifos tridimensionais conforme as orientações de Souza e Oliveira (2012). Os anaglifos gerados foram georreferenciados no software ArcGis 10.0 (Licença de uso Laboratório de Estudos aplicados em Geografia Física da UFPel) e salvos no formato .tif.

A linha de costa lagunar e a planície deltaica do cenário de 2012 foram delimitadas a partir da interpretação de duas imagens do satélite RapidEye, do mês de maio do ano de 2012, com resolução espacial de $5 \mathrm{~m}$ e resolução radiométrica de 12 bits, disponibilizadas gratuitamente pelo Ministério do Meio Ambiente (Geocatálogo MMA). Para a interpretação foram utilizadas as composições coloridas naturais (R3, G4, B5) e infravermelho próximo (Ir). Para a vetorização das feições e edição do mapa foi utilizado o software ArcGis versão 10.0 (Licença Laboratório de Estudos aplicados em Geografia Física da UFPel).

O documento cartográfico final foi organizado de forma a apresentar a configuração deltaica e da linha de costa de forma individual por cenário (1964 e 2012). Posteriormente uma sobreposição destas feições foi realizada a fim de viabilizar a identificação das possíveis mudanças espaciais. A linha de costa vetorizada para os cenários destacados no presente artigo foi delimitada através da interface areia molhada/areia seca. Também foi realizado um trabalho de campo no dia 18 de março de 2016 para reconhecimento e avaliação dos dados levantados nos mapeamentos, organizando eventuais ajustes e comportando assim a reambulação dos dados. Cabe destacar ainda que para a análise dos dados comparativos a área de estudo foi subdividida em cinco setores, a fim de subsidiar a compreenção dos processos costeiros identificados.

\section{Resultados}

A ocorrência de superfícies de relevo plano associadas a este ambiente deposicional favorece o processo de ocupação, sobretudo pelas atividades agropecuárias. No Parque Estadual do Camaquã estas atividades se desenvolveram nas ilhas da planície distributária através de práticas vinculadas ao cultivo de arroz irrigado e da pecuária.

O mapa da linha de costa e do delta intra-lagunar (Figura 2) permitiu a identificação e análise das principais alterações espaciais desencadeadas na área de estudo. Cabe destacar que em 1964 na área em estudo (linha de costa e delineamento do delta intra-lagunar) possuía um comprimento total de 38,93 km de extensão, já no cenário de 2012 ocorre um aumento para 42,79 Km de extensão.

A faixa praial do Parque Estadual do Camaquã apresenta em toda sua extensão duas reentrâncias principais (setores 2 e 4 - Figura 2). Seus limites são definidos por dois pontais: Pontal do Quilombo e 


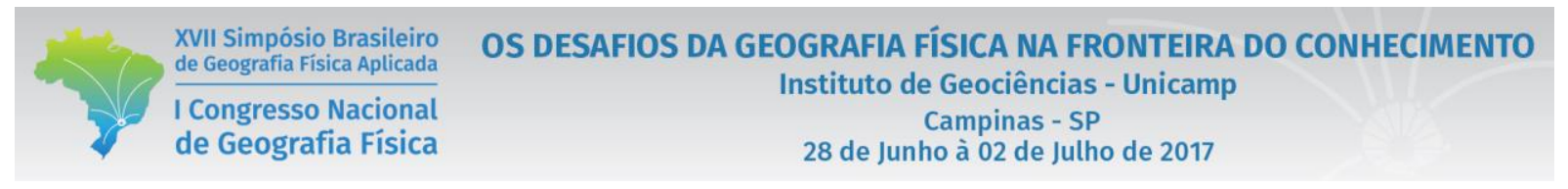

Pontal do Vitoriano (Figura 2), ambos com características morfológicas, sedimentológicas e hidrodinâmicas próprias, as quais serão aqui individualizadas por segmentos de linhas (Figura 02).

No tocante às alterações espaciais da linha de costa lagunar do Parque Estadual do Camaquã foram identificados três setores principais de alterações: um na localidade do Banhado do Caipira (extremo oeste) localizado no mapa como setor 1 (Figura 02); outro setor de alteração foi a desembocadura do delta do rio Camaquã, identificado como setor 3 (Figura 02). Na localidade do Pontal do Vitoriano (extremo leste da área do PEC) identificado como setor 5 (Figura 02). Os segmentos apontados no mapa como setores 2 e 4 são os que permaneceram com pouca ou nenhuma alteração espacial durante o período analisado.

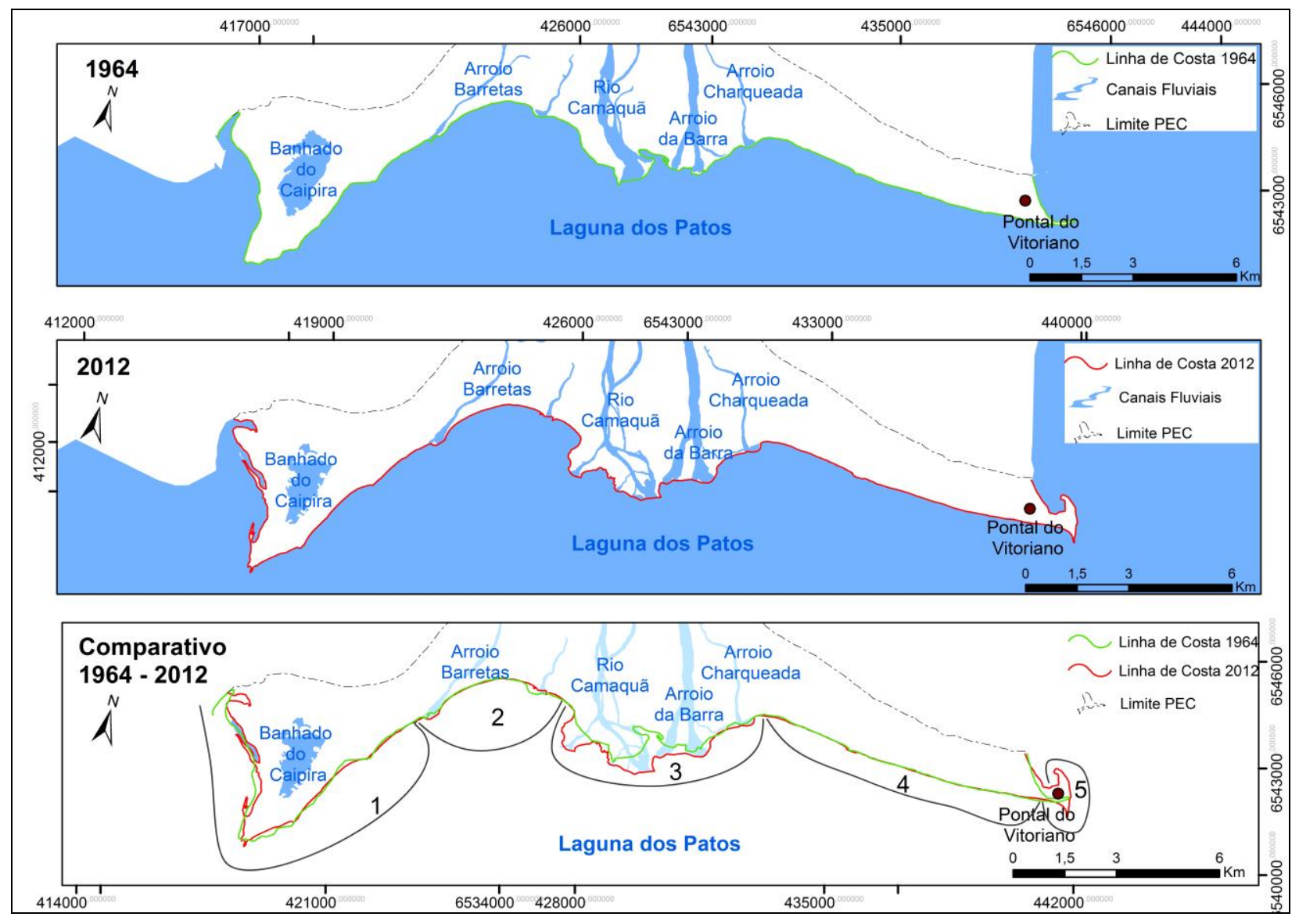

Figura 2 - Linha de costa lagunar envolvendo o Sistema deltaico do Rio Camaquã nos anos de 1964 e 2012 e comparação de ambas em área de abrangência do Parque Estadual do Camaquã. Organização: Ândrea Lopes, 2017.

Cabe destacar que mesmo se tratando de um ambiente protegido por lei são comuns práticas vinculadas à agricultura e pecuária dentro dos limites do parque, como a criação de gado (Figura 3C) e o cultivo de arroz irrigado (Figuras 3A e 3B), tanto na frente deltaica como também na faixa praial e barras de 


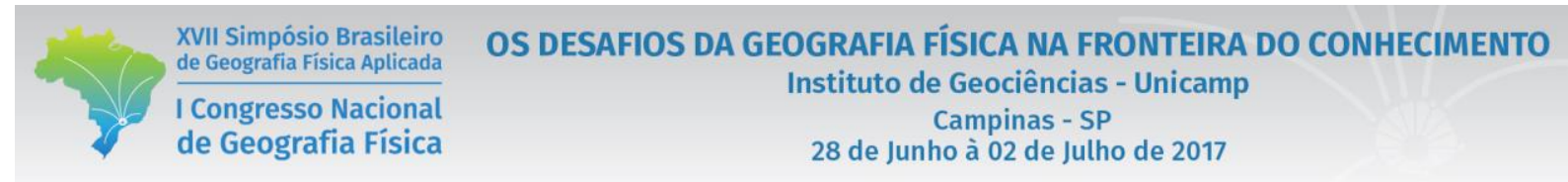

desembocadura (LOPES, 2016; HANSEN, 2007) conforme também pôde ser constatado durante o trabalho de campo.

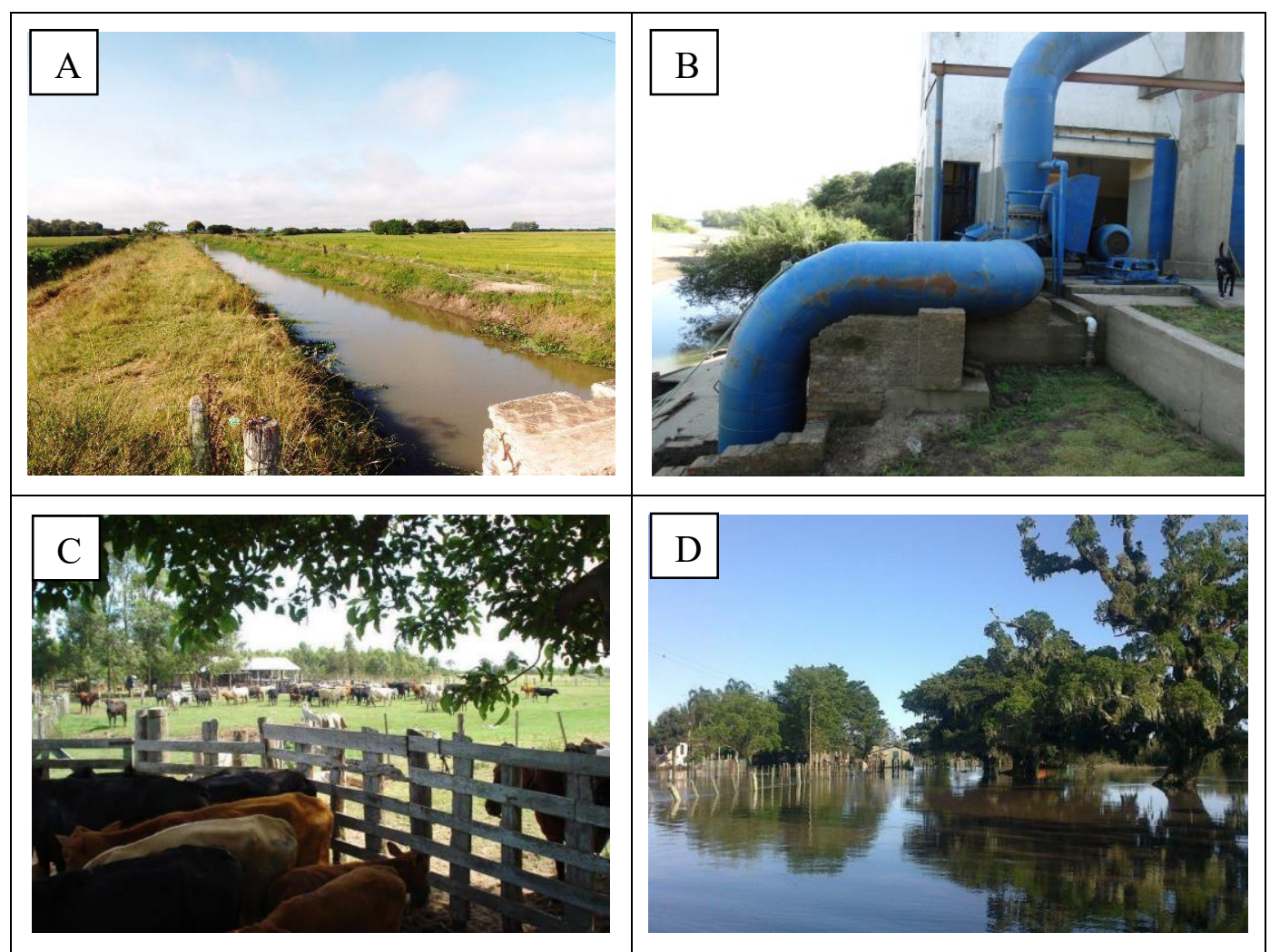

Figura 3 - Intervenções antropogênicas no Parque Estadual do Camaquã. (A) Canal artificial para abastecimento de lavouras de arroz irrigado; (B): Bomba de captação da água do Rio Camaquã para o abastecimento das canchas de arroz irrigado; (C) Pecuária em uma das propriedades localizadas nas ilhas do PEC; (D) Extravasamento fluvial na planície distributária do delta do Camaquã, Ilha de Santo Antônio 15/10/2015. Fonte: Lopes, 2016 e Adriano Kath.

Atividades de cunho agropastoril desencadeiam diversas formas de impactos, uma destas formas é a retirada da cobertura vegetal para o desenvolvimento das áreas de plantio ou ainda áreas de circulação/confinamento do gado, onde as superfícies descobertas ficam expostas aos processos plúvioerosivos desencadeados pelo conjunto de canais distributários que drenam a área constantemente ou pelas cheias que causam o extravasamento do leito e a consequente ocupação da planície distributária marginal (Figura 3D). Além disso, o gado acaba por criar caminhos preferenciais, dinamizando assim processos erosivos e descaracterizando superfícies pelo pisoteamento. A seguir serão analisados os segmentos identificados após a sobreposição das duas conjunturas de linha de costa:

\section{Setor 1: Área de recuo da linha de costa lagunar}

O setor 1 se localiza na área de abrangência do Pontal do Quilombo, na porção oeste do PEC. Conforme análise da Figura 2, trata-se de uma área onde predominou a retração da linha de costa lagunar. Nessa porção do PEC as superfícies são caracterizadas pela ocorrência de planícies flúvio-lacustres 
inconsolidadas, regionalmente denominadas de banhados, e facilmente inundáveis pelas cheias dos canais fluviais e também por eventos críticos (como ressacas) atreladas à dinâmica lagunar (LOPES, 2016).

Esta condição viabiliza o revolvimento contínuo e a erosão do material superficial das áreas de banhado em contato com a Laguna dos Patos. Além disso, a área do Pontal do Quilombo é subsequente de uma reentrância lagunar, isso faz com que a água da laguna circule com maior velocidade, chegando com mais força até o pontal e arrasando as áreas da faixa de praia e o material superficial inconsolidado. Outra explicação vincula-se ao fato desta área possuir canais fluviais de pequeno porte que drenam para a laguna e que contribuem para o arrasamento das superfícies no entorno das desembocaduras.

Apesar da força das ondas não ter ação incisiva na maior parte do ano, de acordo com Toldo Jr., (1994) durante o inverno as ondas na Laguna dos Patos podem chegar a 1,6m, sendo este um importante fator de arrasamento da margem lagunar em especial nas áreas em forma de pontal.

\section{Setor 5: Área de expansão da linha de costa lagunar}

O setor 5 se localiza nas imediações do Pontal do Vitoriano (Figura 2). Nesta porção ocorreu a progradação da linha de costa atrelada a dinâmica deposicional da Laguna dos Patos. Os sedimentos da Laguna dos Patos tendem a ser transportados no sentido nordeste/sudoeste, o que explica essa expansão das áreas de deposição nos pontais da margem oeste da laguna, entre estes o Pontal do Vitoriano.

Outra questão que permeia a formação de pontais na Laguna está vinculada a ação dos ventos no processo de erosão/deposição responsável pela configuração da margem lagunar. Os ventos dominantes são os do quadrante NE. Assim, as margens da laguna apresentam áreas de sucessão entre enseadas e pontais resultantes da ação das ondas e das correntes geradas, criando um processo de retrabalhamento do material advindo da descarga fluvial na lagoa ou sincronizando os processos de erosão das margens em enseadas e de deposição nas margens em pontal.

\section{Setores 2 e 4: Áreas de manutenção da linha de costa.}

Os setores 2 e 4, foram as áreas onde ocorreram poucas ou nenhuma alteração na linha de costa (Figura 2). Cabe destacar que estes dois segmentos estão localizados em reentrâncias ou enseadas. Nesses setores as alterações da linha de costa foram menos pronunciadas, possivelmente em decorrência dos seguintes fatores: (1) nesses dois setores, é quase ausente a desembocadura de canais fluviais de pequeno, médio ou grande porte na Laguna do Patos e isso significa menor aporte de material que sedimenta junto à linha de costa nesses setores e que poderiam contribuir para a progradação; (2) outra questão a ser considerada é que nessas duas reentrâncias são encontradas as faixas de praias mais bem desenvolvidas em extensão, altura e largura de toda a linha de costa lagunar do Parque Estadual do Camaquã, tendo sido estas 


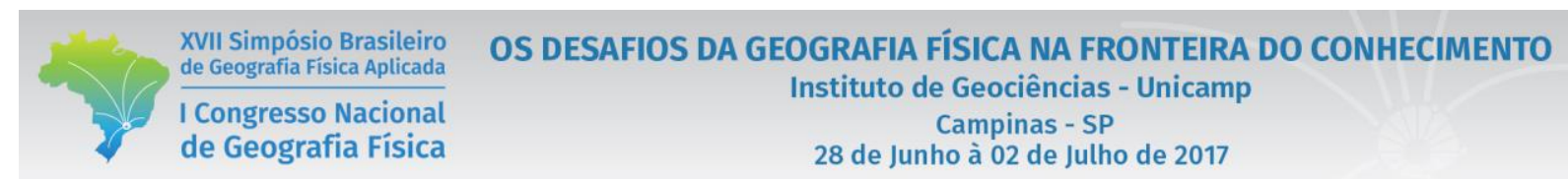

constatações realizadas durante os trabalhos de campo. Este desenvolvimento está atrelado à consolidação da faixa praial e à maior resistência a eventos agressivos da dinâmica lagunar (como no caso de ressacas), fato que contribui para a manutenção de faixas de praia com poucas alterações.

Mesmo não tendo sido verificadas alterações espaciais significativas da linha de costa nesses segmentos existe uma urgência na proteção destes locais, pois estas áreas vêm sofrendo interferências através das atividades socioeconômicas desenvolvidas à montante, principalmente atividades vinculadas a produção de arroz irrigado que interceptam o fluxo de água que chega até o corpo receptor, por meio dos desvios para a drenagem das canchas de irrigação do arroz.

\section{Setor 3: Área de progradação deltaica.}

O delta do rio Camaquã apresenta tendência à progradação da linha de costa (Figura 02), combinada com a consolidação das superfícies de planície flúvio-lacustre e contínuo aporte fluvial do Rio Camaquã e dos Arroios Barretas, da Barra e Charqueadas. De acordo com a Figura 02, no setor 3, verifica-se este aumento nas áreas de sedimentação fluvial que deram origem a diversas ilhas fluviais e barras de desembocadura (Figura 4). O aumento da frente deltaica também pode ser decorrente do retrabalhamento dos depósitos dos paleocordões arenosos adjacentes (Figura 4).

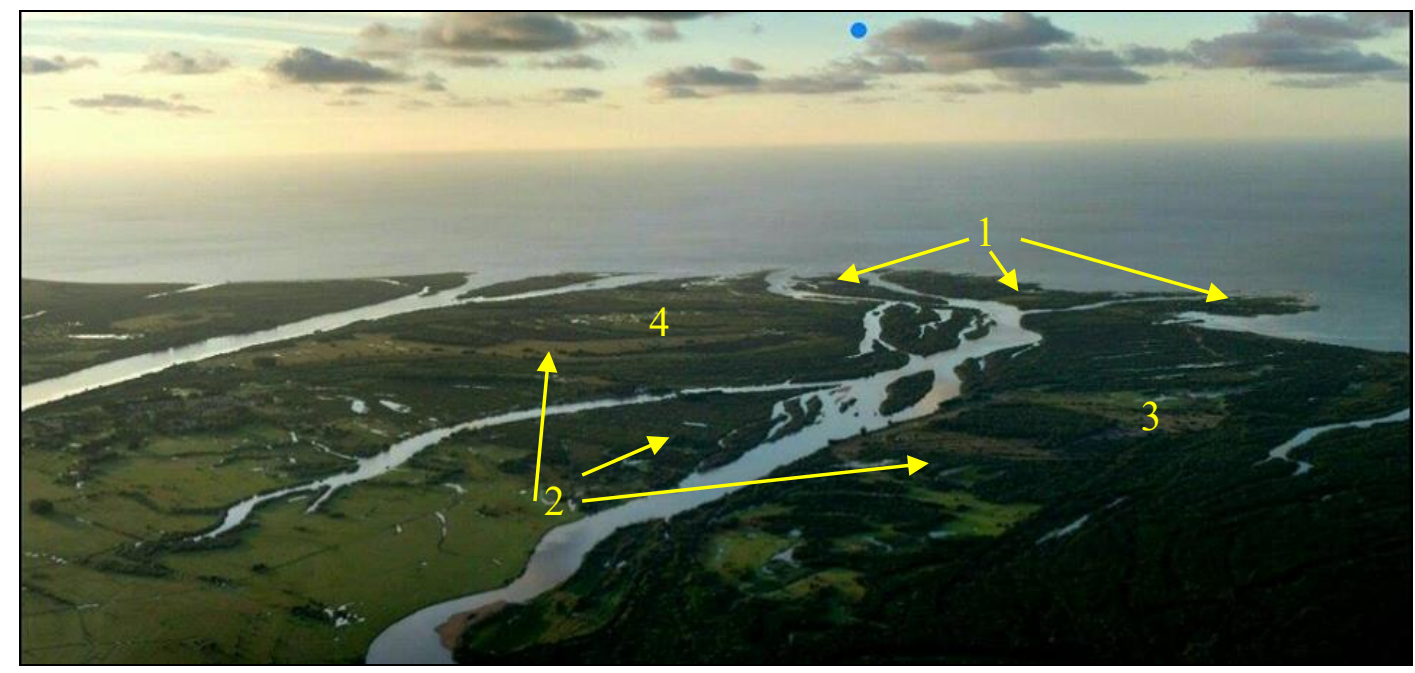

Figura 4 - Vista aérea do delta do rio Camaquã evidenciando em (1) frente deltaica; (2) planície distributária; (3) superfícies de planície flúvio-lacustre; (4) superfícies de paleocordões arenosos. Fonte: Centro de Estudos Ambientais (CEA/RS).

No que se refere ao delta do Camaquã, conclui-se que sua extensão se dá em maior parte como subaérea devido a pouca profundidade da Laguna dos Patos e a pouca influência local das marés. Com relação ao regime de ondas salienta-se a interferência destas nas áreas de faixa praial, sobre os paleocordões arenosos (colaborando para seu arrasamento) e na planície flúvio-lacustre, superfícies localizadas nas planícies distributárias e frente deltaica (Figura 4). 


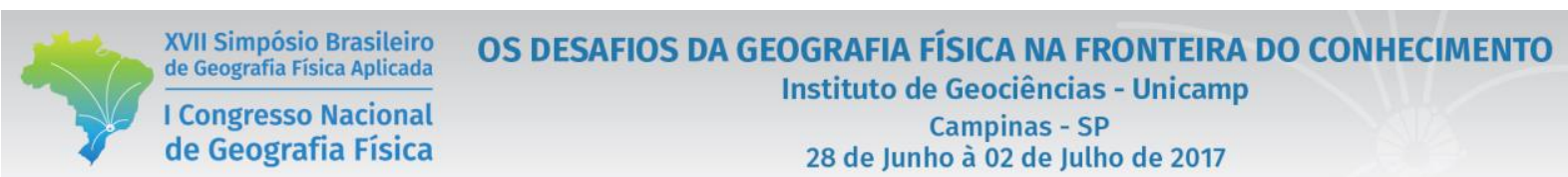

Conforme a análise do mapa de espacialização e comparação do delta intra-lagunar e linha de costa do Parque Estadual do Camaquã (Figura 02) foram possíveis constatar mudanças no padrão do canal distributário principal do rio Camaquã referentes à bifurcação no canal principal, além de um estreitamento dos canais fluviais adjacentes.

A figura 5 apresenta a comparação da área em estudo, a partir dos dois produtos de sensoriamento utilizados. Verifica-se a bifurcação do rio Camaquã, além da formação e consolidação de ilhas na frente deltaica e alterações nas barras de desembocadura dos canais fluviais adjacentes ao delta.

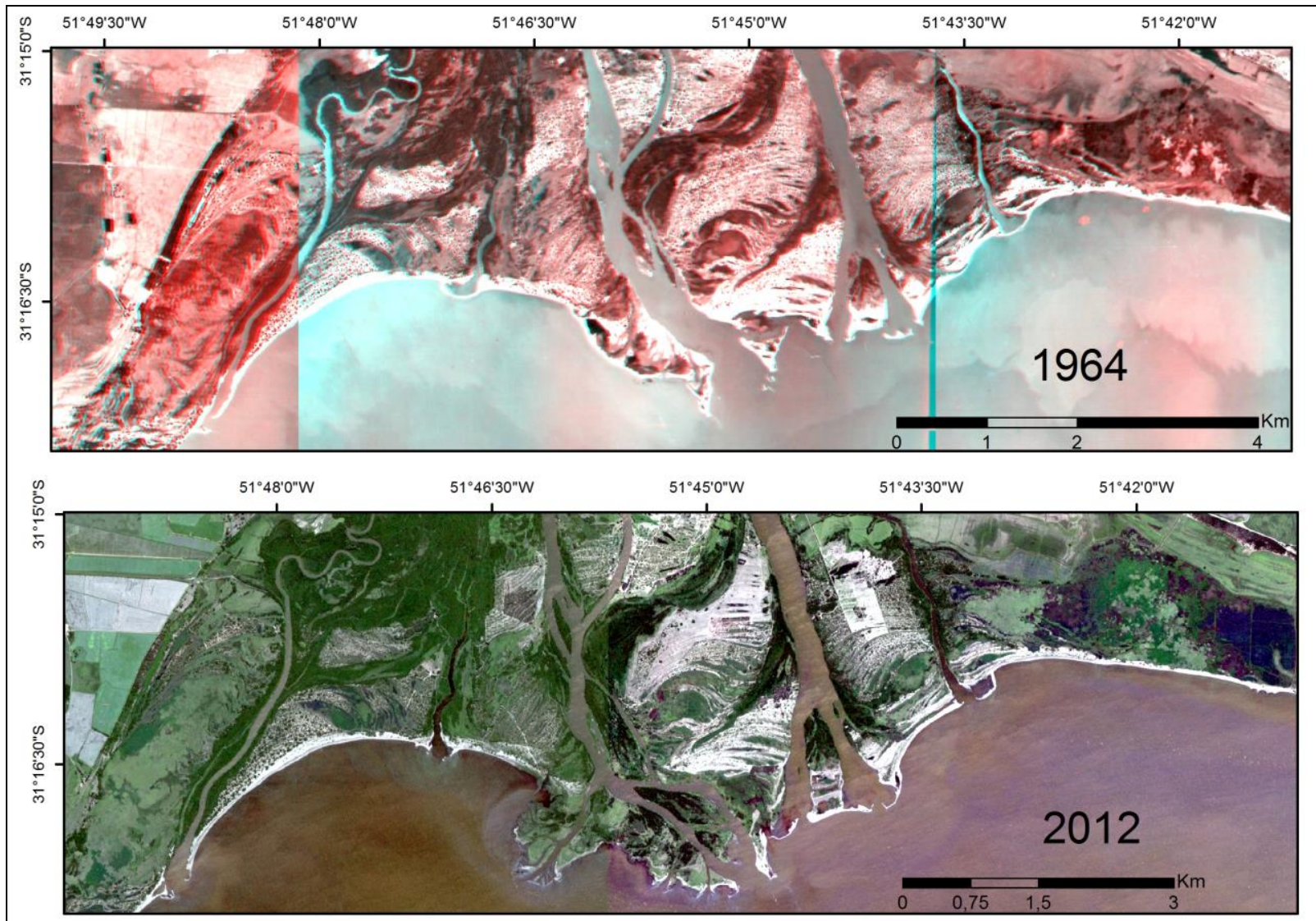

Figura 5 - Imagens da frente deltaica e planície distributária do PEC, na imagem superior fotografias aéreas de 1964 e na imagem inferior imagem de satélite de 2012. Fonte: Fotografia aéreas, SEPLAN/RS e Imagens Satélite Rapidye, MMA.

Esse fenômeno se associa à desiquilíbrios que provavelmente ocorreram à montante do delta, como o barramento do Arroio Duro (um dos principais distributários do rio Camaquã, localizado à montante do Parque), que alterou a vazão do canal e a quantidade de água que chega até a sua foz. A construção do referido barramento teve sua conclusão em 1967, ou seja, após o cenário do primeiro mapeamento.

Outra dinâmica de uso que influencia na configuração do delta está atrelada as lavouras de arroz que sofrem expansão nas áreas marginais ao Parque ou mesmo dentro de seus limites. Este uso demanda a 
captação direta de água do rio Camaquã e de seus distributários por meio de canais artificiais que drenam para as canchas de cultivo ou pequenos reservatórios. De acordo com Hansen (2007) para cada quilograma de arroz são necessários 4.500 litros de água.

\section{Considerações Finais}

A Planície Lagunar do Rio Grande do Sul é resultado das variações do nível do mar ocorridas no Período Quaternário, associada com importantes variações climáticas. Tomando por base o ponto de vista da geologia e da geomorfologia, a planície quaternária é constituída por ambientes recentes, inconsolidados e em constante transformação, caracterizando-se, dessa forma, em áreas suscetíveis a intensas mudanças. Nesse sentido, o planejamento de uso das zonas costeiras não pode deixar de considerar os fenômenos que deram origem e que mantém a dinâmica desses ambientes.

De acordo com a Constituição Federal Brasileira no Artigo 225, parágrafo $4^{\circ}$, a Zona Costeira é um "patrimônio nacional, e sua utilização deverá ocorrer na forma da lei, dentro de condições que assegurem a preservação do meio ambiente, inclusive quanto ao uso dos recursos naturais". Assim, o uso da terra nesse ambiente deve ser planejado e monitorado a fim de promover o uso racional dos recursos.

A análise da variação de linha de costa é um importante dado geomorfológico que deve ser considerado no desenvolvimento do Plano de Manejo desta unidade de conservação, além de auxiliar na delimitação de medidas que visem a recuperação das áreas atingidas. A compreensão da progradação deltaica auxiliará no conhecimento da dinâmica geomorfológica contribuindo no campo científico em estudos que tenham ambientes deltaicos como objeto de análise, visto que ainda são escassos os estudos de ordem geomorfológica e ambiental que avaliem o comportamento de deltas intra-lagunares.

\section{REFERÊNCIAS}

BRASIL. Decreto n 23.798, de 12 de março de 1975. Cria Parques Estaduais e Reservas Biológicas, e dá outras providências.

BRASIL. Ministério das Minas e Energia. Secretaria Geral. Programa de Integração Regional. RADAMBRASIL. Levantamento de Recursos Naturais. Folha SH. 22 Porto Alegre e parte das folhas SH. 21 Uruguaiana e SI 22 Lagoa Mirim. Rio de Janeiro, 1986. v. 33.

Plano Nacional de Gerenciamento Costeiro - PNGC de 1988. Publicado no DOU (Diário Oficial da União) de 18 MAI 1988, Brasília, DF, Brasil. Disponível on-line em http://www.planalto.gov.br/ccivil_03/leis/17661.htm

DOMINGUEZ, J. M. L. Deltas dominados por ondas : críticas às ideias atuais com referência particular ao modelo de Coleman \& Wright. Revista Brasileira de Geociências, v. 20, n. 1-4, p. 352-361, 1990.

FONSECA, Ricardo Carvalho. FALAVIGNA, Tamara. Diagnóstico da Situação e as Ações Prioritárias para a Conservação da Zona Costeira da Região Sul - Rio Grande Do Sul e Santa Catarina. Porto Alegre, 1999.

GUERRA, A. T. \& GUERRA, A. J. T. Novo dicionário geológico-geomorfológico. Rio de Janeiro: Bertrand Brasil, 2008. $648 \mathrm{p}$. 
HANSEN, Marco Antonio Fontoura. Unidades de Conservação Ambiental: Delta do Camaquã e Matas e Banhados da Pacheca, RS (estudo de caso). Ed. Unisinos: 2007. 256p.

LOPES, Ândrea Lenise de O. Zoneamento Ambiental do Parque Estadual do Camaquã: Subsídios ao Plano de Manejo. Relatório de Qualificação de Mestrado. PPGeo/ UFPel, Universidade Federal de Pelotas, 2016, 119p.

MARQUES, Willian C. Padrões de variabilidade temporal nas forçantes de circulação e seus efeitos na dinâmica da Lagoa dos Patos, Rio Grande do Sul, Brasil. Dissertação de Mestrado (PPG em Oceanografia Física, Química e Geológica /Furg) Universidade Federal do Rio Grande, Rio Grande, 2005 87p.

MARTINS, L.R.; TABAJARA, L.L.; FERREIRA, E.R. Linha de Costa: problemas e estudos. Revista Gravel, Porto Alegre, n², outubro/2004, p. 40-56.

MUEHE, D. 2001. Critérios Morfodinâmicos para o Estabelecimento de Limites da Orla Costeria para Fins de Gerenciamento. Revista Brasileira de Geomorfologia, v.2, n.1, p. 35-44.

NICOLODI, João L. A Morfodinâmica praial como subsídio ao Gerenciamento Costeiro. O caso da Praia de Fora - Parque Estadual de Itapuã, RS. Porto Alegre, 2002. 151p. Dissertação de Mestrado (Mestrado em Geociências) Instituto de Geociência da Universidade Federal do Rio Grande do Sul.

ROSSETTI, Dilce de Fátima. Ambientes Costeiros. In: FLORENZANO, Tereza G. (Org.) Geomorfologia: conceitos e tecnologias atuais. São Paulo: Oficina de Textos, 2008 p. 247-283.

SUGUIO, K. Geologia Sedimentar. São Paulo: editora Edgar Blücher Ltda, 2003. 400p.

Wildner, W. Mapa Geológico do Estado do Rio Grande do Sul, escala 1:750.000 . Porto Alegre : CPRM, 2008

TOLDO Jr, E.E. 1994. Sedimentação, Predição do Padrão de Ondas, e Dinâmica Sedimentar da Antepraia e Zona de Surfe do Sistema Lagunar. Tese de Doutorado. Porto Alegre, PPGGEO, UFRGS, 183 p. 